Corresponding Author, Joan Carlini, Dr.

Department of Marketing, Griffith Business School, Griffith University, Parklands Drive, Southport QLD 4222, Gold Coast, Australia, EMAIL: j.carlini@griffith.edu.au

Alexandra Coghlan, Associate Professor

Department of Tourism, Sport and Hotel Management Griffith Business School, Griffith University, Parklands Drive, Southport QLD 4222, Gold Coast, Australia.

EMAIL: A.coghlan@griffiith.edu.au

Department of Tourism, Sport and Hotel Management, Griffith Business School, Griffith University, Parklands Drive, Southport QLD 4222, Gold Coast, Australia, EMAIL: $\underline{\text { a.thomson } @ \text { griffith.edu.au }}$

Andrew O’Neil, Professor

Office of the Pro-Vice Chancellor, Griffith Business School, Griffith University, Parklands Drive, Southport QLD 4222, Gold Coast, Australia,

EMAIL: a.oneil@griffith.edu.au 


\begin{abstract}
Bids for large-scale sporting events and the accompanying political rhetoric typically include promises of economic development and gains for host business communities over the short and long-term. Although conceptual models for economic leverage of large-scale sport events have been developed, our knowledge of the practical experiences of private enterprise converting opportunities presented by large-scale sport events is limited. In this article, the authors address this gap through a case study of the Gold Coast 2018 Commonwealth Games. The article investigates the opportunities and challenges perceived by private enterprises across the host city and explores the implementation of existing strategies to leverage benefits for business. While participants identify the general benefits of hosting the event, they struggle to conceptualise benefits in relation to their own business settings. This suggests a disconnect between the legacy rhetoric of large-scale sporting events and the conversion of these opportunities into outcomes by private enterprises in the host city. Against this background, the article outlines a range of practical implications for private enterprise and key areas for future research.
\end{abstract}

Key words: Private enterprise, Strategic management, Event hosting, Event leverage, Event legacy

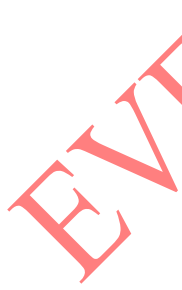




\section{FROM LEGACY RHETORIC TO BUSINESS BENEFITS: A CASE STUDY OF THE GOLD COAST 2018 COMMONWEALTH GAMES}

\section{INTRODUCTION}

Large-scale sporting events can present a powerful tool to enhance the image of a destination and to develop the awareness and reputation of a city or region for business investment, inward migration and tourism development (Getz \& Fairley, 2004; Hall, 2006;

Preuss \& Alfs, 2011). Translating policy into practice is a constant challenge in the management area, including the mega-events sector. How practitioners can best achieve the outcomes and dividends outlined in the academic literature remains elusive in many applied situations, particularly where change in common practice is recommended as business contexts evolve and management must adapt to new situations (Emery, 2010). This has been the case in relation to large-scale sporting events; hosting such events has become "a place-marketing tool in the contemporary urban politics of entrepreneurialism" (Waitt, 2008, p. 154).

The result is increasingly competitive bidding to host events as political and/or marketing tools, with pressure to deliverimpressive and memorable mega-events. Alongside the increased competition, higher promises, greater expectations, and growing expenditure, is a greater need for legitimacy in the eyes of the communities who host mega-events (Smith, 2014). Consequently, the focus has moved from ad-hoc impacts to ex ante strategic planning of event legacies and benefits to local communities (Smith, 2014). Indeed, mega-events have been most commonly framed (and their cost justified) in relation to the public in terms of their benefits to local community (Bob \& Swart, 2010). Most often, these benefits are articulated as economic outcomes, but as this becomes more contested through critical research, the focus of stakeholders and researchers is more commonly directed towards the process through which benefits are 
achieved. Indeed, there is a particular focus on host businesses, as highlighted by as Chalip (2006) and O’Brien and Chalip (2007).

In the Australian State of Queensland, the small business sector plays a crucial role in the economy, comprising $97.4 \%$ of all businesses and employing $44 \%$ of the private sector workforce. The importance of this sector is understood by the Queensland Government, who released the Advancing Small Business Queensland Strategy 2016-20 and launched an Office of Small Business aimed at creating a positive environment for business to operate and grow in Queensland (Queensland Government, 2017). Managing and running a small business in Australia is difficult, with the Australian Bureau of Statistics showing that $15 \%$ do not survive their first year and that $40 \%$ exit within four years. Small businesses are especially vulnerable because the owners are often time-poor, low users of technology, and unsure on how to access optimal information and services (Johnson, 2016).

There are many challenges in articulating the benefits to small businesses of how leveraging concepts can be applied in the planning stages of an event in complex, multistakeholder contexts, where event delivery must be assured alongside enduring benefits for the community (Leopkey \& Parent, 2012). This article explores the perspective of private enterprise, who view themselves as part of the community, and as a critical stakeholder group in need of greater information on how to minimise disruption to their business and better understand the opportunities to leverage benefits from mega-events and their legacy.

\section{LITERATURE REVIEW}

\section{Private Enterprise as Event Stakeholders}

Internationally, it is recognised that privately owned for-profit businesses make a significant contribution to the economy, with the World Bank Group noting that this sector is a 
core element in fostering economic growth, employment and poverty alleviation (as cited in Ayyagari, Beck, \& Demirguc-Kunt, 2007). In Western democratic economies, small to medium business play an important role in the creation of local employment opportunities in regional and domestic economies (Malecki, 2018).). Despite the importance of small business in the economy, the extant research on the economic effects of hosting large-scale sport events has been limited to tourism, hospitality and ancillary operations, with limited research into the effects on other types of local businesses.

In the event management literature, we have seen a demarcation between primary and secondary stakeholders, which is useful in understanding the gap in research relating to the role of small to medium business in realising benefits from large-scale sport events. Primary stakeholders are those that are "vital for the survival of the organisation" and "have high levels of interactivity" with an event (Merrilees, Getz, \& O Brien, 2005, p.1064). Examples of primary stakeholders include TV networks, major private sponsors, government sponsors, merchandisers, and ticketing agencies. Given the dependency of event organisations on these primary stakeholders for the successful staging and delivery of the event, these stakeholders typically exercise the lion's share of input into event planning and access to event leveraging opportunities (Hanstad, Parent, \& Kristiansen, 2013; Todd, Leask, \& Ensor, 2017).

Alternatively, secondary stakeholders are those in the broader realm of the event's host community who may be affected by the mega-event organisation but are not engaged in transactions with the organisation or essential to its survival (Hanstad et al., 2013; Merrilees et al., 2005). Businesses may be positioned within the secondary category, and accordingly, as they are not essential for the successful delivery of an event, it may be unlikely they will attract specific attention in the strategic planning for an event (Merrilees et al., 2005). This means that 
although small business has been identified across the event literature as a key community stakeholder in the hosting of a mega sport event (Smith, 2014), the potential for small business to benefit from hosting strategies remains under-developed. However, if the ambitious economic benefits promised through event hosting strategies are to be secured, there is a greater need to understand how businesses, as secondary event stakeholders, can capitalise on the opportunities presented before, during and after events. This is a significant gap in our knowledge and understanding of the potential economic benefit of mega events. In the next section, we draw together the existing literature to highlight the known opportunities and challenges that may be experienced by small businesses.

The Opportunities and Challenges of a Large-Scale Sport Event for Private Enterprise

Proponents of event hosting strategies typically promote opportunities for increased tourist visitation and stimulating local economies through preparing for, and hosting, large-scale sport events. These economic benefits are typically anticipated to occur in the short-term due to increased tourist visitation and business activity (Hede, 2007; O'Brien \& Chalip, 2007; Weed, 2014). Over the longer-term, returns are anticipated through place marketing efforts, attracting ongoing tourist activity, as well as increased trade and investment in the host destination (O’Brien \& Chalip, 2007). Weed's (2014) study of tourism legacies from the London 2012 Olympic Games also demonstrated that hosting of large-scale sport events provide impetus for urban developments, the reshaping of cities as sites for leisure consumption and attracting investment in host cities in the lead up to and following an event (Smith, 2014). These activities are anticipated to create jobs, stimulate economies and result in gross economic benefits to host cities (Jago, Dwyer, Lipman, van Lill, \& Vorster, 2010). 
However, a number of studies have demonstrated that economic returns from large-scale sport events do not typically meet pre-bid or pre-event expectations (Kasimati, 2003; Tien, Lo, \& Lin, 2011). Out another way, the substantial investment in capital projects does not guarantee the significant prosperity promised. For example, KPMG prepared a report for the Sydney 2000 Olympic Games' bid in 1993 that predicted it would add \$7.3 billion to the economy and create 156000 new jobs. In contrast, a post-event analysis by Monash University found that the Olympics "in purely measurable economic variables...had a negative effect on New South Wales and Australia as a whole"; that is, a net consumption loss of $\$ 2.1$ billion(as cited in Thompson, 2015). Similarly, while Weed (2014) was able to find the London 2012 Olympic Games secured outcomes including increased business capacity, increased tourism expenditure and urban regeneration, he did not see these outcomes justifying the $£ 9.3$ billion public sector investment in the event. In the next section we examine the existing research to consider the potential opportunities and challenges of a large-scale sport event for local businesses in terms of i) tourism visitation and place marketing; ii) urban development; and iii) stimulating local business.

Tourist visitation and place marketing. Events are perceived as an important vehicle for tourism development in terms of adding to the tourism experience, as well as in the longerterm contributing to thelplace marketing and appeal of a tourist destination (Sun, Rodriguez, $\mathrm{Wu}$, \& Chuang, 2013; Weed, 2014). However, economic analysis of the tourism benefits from largescale sport events have highlighted that while these events provide important media and marketing opportunities, they are not without challenges. Tourism expenditures are typically a large contributor to the overall economic impact measurement of a large-scale sport event (Preuss, 2011), and these measures are reliant on the additional visitation and expenditure of tourists who come to a destination specifically for the purposes of attending an event. Economic 
impact analyses over the years have highlighted that we cannot assume an event provides an overall gross benefit because the staging of an event can have unintended consequences of displacing expected visitors through 'time switching' and/or 'crowding out' effects (Preuss, 2011). Time switching occurs when tourists visit at another time to avoid the event hype and congestion. In contrast, the crowding out effect occurs when tourists who might have normally travelled to a destination decide to travel to an alternative destination. The literature emphasises the importance of anticipating these effects, as well as the need for tourism and hospitality operators to ensure they are maximising tourist spending during their attendance at an event (Mackellar \& Nisbet, 2017).

Sport events have a unique global appeal compared to other tourism assets, and the potential television audiences and potential place marketing effects to profile destinations and shape perceptions have long been a key justification by event proponents to bid for hosting rights (Xing \& Chalip, 2006). However, potential place marketing effects have also been highlighted as ambiguous and complex. Fairley, Lovegrove, Newland, and Green (2016) discussed a recent example from the Gold Coast, Australia, the focus city of our current study. The 2014 Pan Pacific Swimming Championships was held at the Gold Coast Aquatics Centre, a venue newly renovated as part of thellonger-term hosting strategy for the Gold Coast 2018 (GC 2018) Commonwealth Games (Gold Coast 2018, 2017). Fairley et al. (2016) found that the unseasonably cold and rainy conditions experienced at the weather-exposed venue were perceived to affect swimming performance and detract from the spectator experience. These perceptions were communicated to a global audience via social media and may have ultimately detracted from the host government's intention to promote visitation to GC2018 through the Pan Pacific Swimming Championships. 
Furthermore, a recent report by global consulting firm, PricewaterhouseCoopers (PricewaterhouseCoopers [PwC], 2017) further highlights the complexities of sport events and place marketing effects, suggesting technological advances in media broadcasting will provide broadcasters with an improved ability to target associated advertising to digital consumers. In addition, fans will be provided with more autonomy in the way they consume sport (PwC, 2017). This presents challenges for host governments and destination management organisations in how they leverage event broadcasting and associated media to profile their destinations through broadcasts of sport events.

Urban developments. The hosting of large-scale sport events is typically regarded as catalytic for urban development and renewal, and in particular the creation of new precincts for tourism and consumption of leisure experiences (Essex \& Chalkley, 2004; Kassens-Noor, Wilson, Müller, Maharaj, \& Huntoon, 2015; Smith, 2014). Prompted by the necessity to host a large number of sport event tourists, hotels and sports venues are typically developed in host cities with the anticipation that longer-term resident and tourist demand will meet the increased supply of new homes and hotels. The most successful sport event-related urban development occurs when the hosting of an event accelerates existing initiatives for community and/or urban development, as was the case in Barcelona 1992 (Gratton \& Preuss, 2008). However, there are many instances where ad hoc and reactive development has negative outcomes for the host city and its residents. For example, the cost of the 2014 Sochi Winter Olympics was $\$ 55$ billion, up from the estimated $\$ 12$ billion at the time of the bid (Müller, 2012). The reported benefits for the host city can therefore be limited, with excessive hotel overcapacity, investors defaulting on loans, and no coherent plan for post event use of venues. 
A typical approach by host cities has been to take deindustrialised precincts, or brownfield sites, and redevelop these as sites for modern mixed developments of residential, commercial and entertainment (Brahham \& Spink, 2012). The development of Athletes' Villages is a common example of this. In many instances, the villages are developed as social housing initiatives to provide new low-cost and welfare housing for a host city. However, there have been a number of studies highlighted by Thomson, Schlenker, Schulenkorf and Brooking (2017, p. 154-156) which expose how many vulnerable people are displaced in the course of constructing such projects, putting pressure on social housing and disrupting existing communities (Bernstock \& Poynter, 2012). After the villages are constructed, many host cities have committed to making the housing available to parts of the community eligible for low cost or social housing. However, there are several examples where the actual construction costs far exceeded initial estimates, and apartments have had to be sold on the free market to recoup costs. The 2010 Vancouver Winter Olympics provides a good example of this (Pentifallo \& VanWynsberghe, 2015). In other cases, there has been no commitment to social housing agendas, and villages are on-sold to the free market, meaning areas that may have once been affordable working class neighbourhoods are now only accessible for people who can afford to live in gentrified areas. Features such as proximity to sporting venues and entertainment precincts have also been demonstrated to increase property values; the mere speculation of venue development is enough to have an upward impact on property values (Ahlfeldt \& Kavetsos, 2012). Unfortunately, this also means people in lower socio-demographic groups are likely to be priced out of these neighbourhoods over time (Thomson et al., 2017).

In terms of hotel development, studies have shown that despite long-term pre-event planning, hotel occupancies can often fall short of expected demand, in turn impacting on the 
economic gains promoted in event rhetoric (Barreda, Zubieta, Chen, Cassilha, \& Kageyama, 2017; Sun et al., 2013). In the case of the 2009 World Games hosted in Taiwan, Sun et al. (2013) found a range of factors contributed to lower than expected occupancy rates, including inefficient collaboration between stakeholders, competition from hotels in regional areas, and a perception of an unfriendly local area associated with illness, climatic conditions and political controversies. They identified an increased need for collaboration between stakeholders, and the sharing of information and risk. In addition, often the increased supply of accommodation stock in a host city secured in the lead up to an event is underutilised post-event (Demir, Eliöz, Çebi, \& Yamak, 2015). There are examples of temporary accommodation options which have been utilised to combat issues of oversupply post-event, such as cruise ships being used as temporary accommodation for Sydney 2000 Olympics (Ferson \& Ressler, 2005), Athens 2004 Olympic Games (Samatas, 2014), and motorhomes and self-drive holidays promoted for the 2011 New Zealand Rugby World Cup.

Stimulating local businesses. The hosting of large-scale sport events is typically portrayed by proponents as stimulating a local economy due to cash injections brought about through associated expenditures. However, studies generated throughout the 1990's demonstrated that although construction and tourism enterprises benefit from the cash injection brought about through hosting a large-scale sport event, many local merchants are likely to be negatively affected as a result of hosting large-scale sport events (Chalip, 2017; Chalip \& Leyns, 2002). Recently, Kwiatkowski’s (2016) systematic review of event attendees' expenditure patterns found that during events, expenditure patterns by local residents change temporarily. For instance, residents wanting to avoid local event-related traffic congestion may stay at home, therefore spending less than normal. In other cases, locals may spend more than they normally 
would; but there is a lack of empirical investigation into this scenario. Kwaitkowski (2016) concluded these behaviours have impacts for economic modelling and require further research.

Chalip (2017) highlighted that while all taxpayers fund the staging of an event, it may only be the tourism, hospitality and ancillary businesses situated within the vicinity of an event that benefit economically. Smith's (2014) study highlighted the potential for negative impacts on local business brought about by the urban regeneration efforts surrounding the London 2012 Olympic Games. The urban regeneration program effectively displaced local businesses - many that had been operating for decades - from affordable industrial and commercial inner-city areas to make way for new residential and retail developments.

Perhaps in part due to the realisation that events are not always automatically good for all businesses, we have seen other business benefits highlighted in political rhetoric. For instance, the notion of place marketing has been broadened as not only beneficial to tourist visitation, but also a tool used by host governments to signal that the host city and/or nation is a place to live, work and do business (Dolles \& Söderman, 2008; Smith \& Fox, 2007; Weed, 2014). There is also the potential for new business creation to service the sport event industry (Dolles \& Söderman, 2008) through proximal development effects, whereby flagship investment in sport stadia to prompt ancillary industry development (Crompton, 2014).

We have also seen an increased emphasis since the London 2012 Olympic Games on the potential pre-event economic impact where it is possible for business to derive gains through procurement opportunities to construct event venues, related infrastructure and other preparations (Smith, 2014; Weed, 2014). Weed (2014) highlighted how a specific London 2012 Olympic Games legacy strategy, 'CompeteFor' enabled UK based businesses to compete for and win event-related contracts. The outcome of this strategy was that $98 \%$ of contracts were 
awarded to UK based companies, two-thirds of these being small to medium enterprises (Weed, 2014). Weed (2014) also highlighted that this business activity represents an immediate impact but cautions that the long-term benefit to the business sector depends on the ability of businesses to engage with the ongoing opportunities presented through government procurement.

\section{Activating the Opportunity}

Across each of the three areas outlined above (tourism visitation, urban development and stimulated local businesses) the literature underscores that these positive outcomes do not occur automatically. In fact, where positive outcomes have occurred, they have been facilitated through strategic initiatives beyond the mere staging of an event (Chalip \& Leyns, 2002; Smith, 2014).

One approach to activating opportunities has been through event leveraging strategies, developed by Chalip and colleagues since the early 2000s. Chalip (2001) pointed out that event impacts and legacies are only as good as the strategic planning implemented to support them. Chalip, Ritchie, and Adair (2004, p. 245) subsequently argued, it is no longer suitable merely to host an event in the hope that desired outcomes will be achieved; it is necessary to form and implement strategies and tactics that capitalise fully on the opportunities each event affords'.

Chalip and others (Chalip, 2006, 2017; Chalip, Green, \& Hill, 2003; Chalip \& Leyns, 2002; Chalip et al., 2004; Gardiner \& Chalip, 2006; Kellett, Hede, \& Chalip, 2008; O'Brien, 2005, 2007; O'Brien \& Chalip, 2007) have been at the forefront of considering how mega-event planners and event stakeholders can strategically build legacy outcomes into the planning and design of events. These contributions highlight the importance of recognising the opportunity presented by event hosting strategies and following through on this by investing in strategic initiatives to capitalise on the opportunities presented. While conceptual models for economic leverage of large-scale sport events have been developed, they have largely focused on tourism 
and hospitality stakeholders located within an event precinct which we would expect to be motivated to capitalise on the opportunity of hosting a large-scale sport event (Chalip \& Leyns, 2002). Little investigation has taken place of the broader context of business, particularly those that are considered secondary stakeholders within a host destination (Hanstad et al., 2013; Tiew, Holmes, \& De Bussy, 2015; Todd et al., 2017).

Activation of opportunity requires positive action (that is, proactive initiatives and planning) by small businesses to leverage benefits associated with a large-scale event. A distinction of activating opportunity is that the initiatives are separate from, but related to, the delivery and management of the event (Smith, 2014, p. 23). O'Brien (2005, p.2) framed this most simply, observing that "mega-events and the opportunities they present are merely the seed capital, what hosts do with that capital provides the longer-term legacies". As outlined in an earlier section, the positioning of small business as a secondary stakeholder means this group is less likely to receive specific attention to encourage or support leveraging activities, and if they are to maximise the opportunities and limit the negatives presented through the hosting of a large-scale sport event, they will need to be self-driven.

Meanwhile, existing literature has highlighted the need for coordinated approaches to leveraging to maximise gross benefits and contribute to the overall festival feel of the focus event (Cashman, 2006; Cashman \& Horne, 2013; Chalip, 2006, 2017; Chalip et al., 2003; Chalip \& Leyns, 2002; Kellett et al., 2008; O'Brien, 2005, 2007; O’Brien \& Gardiner, 2006; Veal, Toohey, \& Frawley, 2012). Chalip and Leyns (2002) argue that stakeholders should be coordinated to provide the best possibilities for securing legacies and encouraging the equitable distribution of benefits from large-scale sport events. Where event leverage is coordinated, the outcomes are generally maximised across stakeholders, both primary and secondary (Chalip, 
2001; Chalip \& Leyns, 2002; O'Brien, 2005, 2006, 2007). O’Brien (2005) extends this notion of coordination, highlighting the importance of stakeholders being encouraged not only to act, but to act in a timely manner. Similarly, researchers have found that where resources, such as financial and human resources are not dedicated to event leverage initiatives, potential positive outcomes are often inhibited (O’Brien, 2006; Kellett et al., 2008). O’Brien's (2005, p.vi) investigation into business leveraging of the Sydney 2000 Olympic Games, found that “potentially significant business opportunities went unrealised due to insufficient resource allocation".

Although the event leverage literature has established the importance of coordination and resourcing, the questions of who should be responsible for coordinating and providing resources has acquired limited consensus. Chalip and Leyns (2002, p.154) suggest that event organisers have 'the most to gain if leveraging is fostered, and the most to lose if leveraging remains haphazard'. For instance, event organisers are able to justify public subsidies of events if economic returns are maximised but suffer the greatest criticism if leverage strategies are poorly executed, especially if these affect event brand and sponsor investments. However, O’Brien (2005) argues that event organising committees are often only temporary organisations, dismantled soon after an event has concluded, making it impractical for these organisations to be responsible for encouraging stakeholders to capitalise on opportunities post-event. In terms of economic event leverage, O’Brien (2006) highlights the tension that arises when governments invest in and coordinate initiatives for private sector gain in relation to whether this is an appropriate investment of taxpayer funds. In contrast, in the context of social event leverage, Kellett et al., (2008) argue that governments have a greater role to play in investing and coordinating initiatives to bring about social legacies. 
The event legacy literature has begun to delve into the issues of responsibility and governance to secure outcomes (Christie \& Gibb, 2015; Leopkey \& Parent, 2013). A recent study (Christie \& Gibb, 2015) conducted in a broader urban regeneration context for the Glasgow 2014 Commonwealth Games highlighted the need for partnership approaches to leverage a large-scale sport event to secure benefits for the host community. The partnership approach implemented across the public sector (e.g. the Glasgow City Council and the Scottish Government), the event managers (e.g. the Commonwealth Games Councilfor Scotland and the Commonwealth Games Federation), and third sector organisations exemplified a shared vision/agenda and mutual understanding, resource pooling, leadership and engagement, leadership, accountability and trust (Christie \& Gibb, 2015).

Borrowing from more recent research in the tourism management field, Coghlan, Sparks, Liu, and Winlaw (2017) suggest that ensuring a community benefits outcome from events may in fact require an external agent, allowing the primary stakeholders to focus on the successful staging and delivery of an event. In their study, they found that collaboration between academics (that is, an external agent) and precinct managers assisted in bridging a gap between the theory and practice of place making, with collaborative efforts informing event design to maximise the economic outcomes of an event, and at the same time, improve community engagement and event outcomes for local communities. Schulenkorf (2010) identified a similar, but informal process in his study of the role of external agents in delivering community benefits through sport. Among the roles he identifies for a successful change agent in the sport context are a trust builder, networker and strategic planner. In the next section, we detail the research design developed to investigate the issue of a secondary stakeholder group activating benefits. 


\section{RESEARCH DESIGN}

\section{Background}

The research resulted from a collaboration between Griffith University’s Business School and its advisory committee, the 'Friends of Griffith Business School' (FoGBS). The aim of the FoGBS is to increase the collaboration between the School and the Gold Coast business community. The FoGBS have a particular focus on private enterprise and seek to provide research that is a vital resource for Gold Coast businesses in driving improyement and sustainability. In the first collaboration, the FoGBS sought to explore the impact, opportunity and legacy of the 2018 Commonwealth Games for private enterprise. The FoGBS motivation for commissioning the research was that they believed GC2018 is one of the most significant events for the Gold Coast and that understanding the resulting opportunities and challenges is vital.

The FoGBS stated they felt a lack of awareness about the Gold Coast 2018 Commonwealth Games, and in particular, what GC2018 meant for their businesses. On close inspection of the GC2018 bid document (City of Gold Coast, 2011), it became clearer that the host city's communications programs to cultivate local support and interest is limited to working with tourism organisations; sporting stakeholder networks, the promotion of Gold Coast City as a 'hub' for world class sporting activity and involving the community through sport development programs. It is evident from the bid document that private enterprise as a stakeholder group was overlooked during the event's conception

\section{Research Aim}

The study aimed to understand the perspective of private enterprise as an event stakeholder with particular information needs concerning how best to minimise disruption and 
maximise opportunities in order to leverage benefits from mega-events and their legacy using the 2018 Gold Coast Commonwealth Games as a case study.

\section{Research Approach}

The aim of the study justified a qualitative approach utilising an inductive method. Existing theory was used as the foundation to construct a purposeful study focused on knowledge creation by exploring this unique case. Studying a diacritic case through fieldwork provides the opportunity to gain insight and explore how the phenomenon of interest exists within the real world (Neuman, 2006; Yin, 2011). The single case study selected was the Gold Coast Commonwealth Games (GC2018). The GC2018 is first mega sport event hosted in Australia in over a decade and the first large-scale sporting event to be held on the Gold Coast.

\section{Case study: The Gold Coast 2018 Commonwealth Games. The Gold Coast}

Commonwealth Games will be held over a two-week period from 4-18 April 2018. The Gold Coast City filed its bid for the event in 2011, which was based on a city with mature safety, security, transport, technology, accommodation and a reputation of major international and international events. The biddocument stated that additional benefits to the City and region included increased multicultural awareness; sport development through increased participation in physical activity and interest in Commonwealth Games sports; sports administration and management opportunities; increased business and employment; increased tourism; up-skilled workforce due to training, educational benefits and community engagement (City of Gold Coast, 2011).

The event is expected to create up to 30000 jobs and inject $\$ 2$ billion into the State economy (Queensland Government, 2017). It will be the largest sporting event held in Australia this decade, with approximately 6500 Athletes and 1200 technical officials attending, and a 
global audience of 1.5 billion, and 1.5 million ticketed spectators. The event is expected to attract 100000 domestic and international visitors to the Gold Coast, as well as other Queensland urban centres of Cairns, Townsville and Brisbane which will also host some of the sporting events.

The event is planned, organised and delivered by the Gold Coast 2018 Commonwealth Games Corporation (GOLDOC, 2014) established by the state government of Queensland through the Commonwealth Games Arrangements Act 2011 (Q1d). GOLDOC works in conjunction with the five key delivery partners, including; The Queensland state government (via the Office of the Commonwealth Games [OCG]); the City of the Gold Coast; the Australian Government (via the Office for Sport); the Commonwealth Games Federation (CGF) and Commonwealth Games Australia. A range of other government and non-government partners are also engaged accordingly.

While GOLDOC are responsible for the majority of Functional Areas (FAs) set out in the CGF's event manual, OCG are responsible for the Legacy FA, reflecting the longer-term commitment by the State government to derive benefits for Queensland through investment in hosting GC2018. Also, at the state government level, the Department of State Development (DSD) is responsible for the delivery of the Games infrastructure program, a key part of the tangible legacy of GC2018. To support the realisation of legacy benefits through GC2018, GOLDOC has a dedicated Sustainability and Legacy team sits within the Planning and Readiness division, and works with all other Functional Areas to ensure that "legacy opportunities are being identified across the organisation, to report on our sustainability performance and to support each FA to ensure that sustainability and legacy considerations are embedded within planning and delivery" (GOLDOC, 2014). As the host city, the City of Gold Coast local government authority is responsible for maximising the city's legacy through the 
event and arts and cultural program initiatives. The City of the Gold Coast will also be the final asset owner of many of the venues. The GC2018 footprint extends more than $100 \mathrm{kms}$, with events distributed from the Queensland state capital, Brisbane, to Coolangatta, the southernmost point of the State.

In terms of media exposure, it is expected that the Games will receive 1000 hours of television coverage, broadcast to a 1.5 billion global audiences, 10000 media articles about the Gold coast, and welcome 3000 accredited and non-accredited media representatives (Gold Coast 2018, 2017). This media coverage is anticipated to generate significant exposure for the region as a tourist destination as well as, in the words of one government Minister, “showcasing our city's reputation as a place of unique opportunity with an enviable lifestyle - a place where people can live, work, study and invest" (Jones, 2017). The Gold Coast has undergone substantial regeneration with a surge of investment in the lead up to the Games. The City's infrastructure has benefited with significant funding concentrated on infrastructure, sporting facilities, transport and housing; for example, the newly constructed Commonwealth Games Village provides 1,252 residences, the city's light raik is being extended to link with trains arriving from the State capital of Brisbane, five new or upgraded sporting venues, and well as regeneration projects in several beachfront areas, and public art projects linked to the Games. To assist businesses in realising benefit the OCG have created information sheets targeted at small business within the host community, which outline how small business can be "Games Ready".

\section{DATA COLLECTION}

\section{In-depth Interviews}

Data were collected over a six-month period (January 2017 to June 2017), a pre-event period which covered GC2018 “one-year to go" celebrations, a critical milestone in the event 
planning. In-depth interviews lasting up to one hour were conducted. Manual notes taken during interviews were later drafted as memos and incorporated into the data analysis.

\section{Sampling}

As the scope of this study is concerned with exploring and describing a contemporary real world phenomena, a purposive sampling method was used to ensure that the case is rich and empirically relevant to the phenomenon of interest (Etikan, Musa, \& Alkassim, 2016). Our sampling reflected a staged approach, including:

- Stage 1: We commenced with a purposive sampling approach-based on an understanding of the literature and context of the mega-event, key stakeholders were identified as part of the purposive sampling approaches, ineluding private enterprises, event organising committee and local government. The FoGBS supplied a list of businesses in various industries to assist in gaining a variety of perspectives.

- Stage 2: We progressed with targeted theoretical sampling - based on thematic findings from preliminary analysis of data captured in initial sampling (similarities in observations were grouped, patterns identified, with new or surprising observations pursued further), more participants were identified, including: academic experts and industry bodies to further explain observations (Sbaraini, Carter, Evans, \& Blinkhorn, 2011).

- Stage 3: We concluded the process with an industry forum. The invited research participants, private enterprises and stakeholders from across the Gold Coast region to view preliminary findings from the study, participate in a question, and answer panel scenario. The lead researcher presented research findings and emergent themes to the 87 guests (representing the range of stakeholder groups identified as being relevant to the study). The subsequent panel included two private enterprise speakers and an industry 
group representative, who answered audience questions after the presentation. The lead researcher viewed footage of the event and searched for any emergent themes not already reflected in the preliminary finding (Ritchie \& Smith, 1991).

This approach resulted in a final sample of 34 interview participants, as shown in Table 2. Ten participants were from private enterprise, representing sectors including finance, retail, tourism, information technology, telecommunications, and supply chain. A further four participants were drawn from industry groups representing sectors includíng: catering, accommodation, business development and tourism. Two participants were from City of Gold Coast and two from the Queensland State Government. Finally, one member of the event organising committee and 15 experts in sport, event, education, urban planning, human resources, marketing and clinical psychology were interviewed.

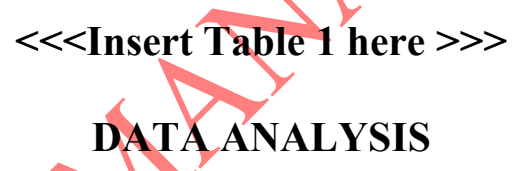

A constant comparative method including hand written notes made during each interview, that were later translated into memos including observations and reflections aided the approach. In discussion with the other authors, the lead researcher open coded data manually with a thematic framework emerging, with each progressive interview coded against existing themes, and consequentially influencing questioning of subsequent interviews. In-line with the study's aim, data were carefully considered in terms of business opportunities, challenges and activation strategy, if any. Importantly, to distinguish between different stakeholder views, data from each group were coded against the same themes but were identifiably different. Later, each of the themes were summarised for each stakeholder group. 
The lead researcher continually reflected on what she had learned from the interviews, and made comparisons across the memos, and used figures and tables to create meaning. At a conceptual level, the focus on similarities to existing knowledge, and divergences were noted for further investigation. After the data analysis and memo writing, additional participants were sought to contribute to, and expand the scope and substance of, the analysis. Some participants were contacted for a member-checking process to clarify their comments during the interview (Tracy, 2010). Some adjustments were made to the coding accordingly.

\section{LIMITATIONS OF THE RESEARCH}

Perhaps the most serious limitation of this study was its narrow focus on the host city for the 2018 Commonwealth Games, thus precluding the surrounding non-host cities and regions. This may be problematic as the basketball heats are to be held in Townsville and Cairns. Similar to the Gold Coast, Townsville and Cairns rely heavily on the tourism market for city prosperity. A further limitation may be that the study was conducted ex ante and is therefore based on expectations rather than actual results. However, as discussed by (Teigland, 1999), ex ante assessment made by local and national authorities for events have long-term impacts on the host city due to its effect on decision-making.

\section{FINDINGS}

Three main themes emerged through the data analysis included: 1) perceived benefits for the Gold Coast; 2) potential challenges and 3) considerations for business to leverage benefits. A visual summary of these main themes and subthemes is included in Figure 1, and further explored in-depth below.

\section{$<<<$ Insert Figure 1 here $>>>$}




\section{Perceived Benefits}

In terms of event benefits for the wider community, the participants' responses confirmed many of the themes presented in the literature with regards to the type of event-led benefits we might expect from hosting the Commonwealth Games. Six themes emerged from the analysis, including; increased tourism demand and supply, upskilling and civic pride, lever for future events and development of a sports industry, improved image/employer brand, accelerated infrastructure and higher real estate prices, as presented below. Table 2 highlights the contrasting views from the different stakeholder groups, which is discussed in more detail below. $<<<$ Insert Table 2 here $>>>$

Increased tourism demand and supply. Many participants highlighted that there would be more visitors on the Gold Coast, with the influx of athletes, officials and associated visitors. One of the hotelier participants said that they had been in negotiations with the organising committee and had committed a large number of rooms but were concerned because GOLDOC could cancel any time leading up to the games. She noted that they had been cautious in price setting accommodatiøn for the GC2018 because during the Sydney Olympics their hotel had over priced rooms; consequently, the Sydney property was left with vacancies.

"The majority of our rooms have been secured by GOLDOC for visiting delegates, media or corporate sponsors." Participant 31 - Private enterprise, accommodation

Three participants spoke about new accommodation being built ready for GC2018 visitors; however, four participants spoke about Airbnb and how they expected that many visitors would use the sharing economy. Two industry group participants showed concern with the 
potential use of Airbnb suggesting that the lack of regulation, difficulty in assuring quality and spending leakage due to self-catering from the hospitality sector could present problems.

"We are concerned about the spending leakage that occurs through Airbnb because visitors tend to use the kitchen facilities in the house and not dine in restaurants" Participant 14 - Industry group, accommodation

Upskilling and Civic pride. The participants highlighted the potential to upskill local residents through the volunteer program. One of the participants mentioned that the early success in volunteer registration showed community enthusiasm. Another participant was concerned with the transfer of GC2018 volunteers to other community organisations after the Games. He suggested that GC2018 volunteers might be a valuable source of untapped social capital, which may not be fully utilised.

"GC2018 has meant upskilling of local residents; this will be a lasting legacy of the event" Participant 1 - Académic expert - event and sport management Additionally, a local government participant spoke about the community outreach program, an initiative of the City of Gold Coast designed to engage and stimulate civic pride. Two participants commented about the satisfaction of locals with the improvements that are occurring throughout the city.

"The Gold Coast is a buzz of excitement; all the improvements around the city have everyone in a good mood. The city looks good, not so tacky anymore." Participant 8 Private enterprise, tourism

Lever for future events and developing sports industry. One of the academic expert participants spoke about the opportunity to diversify industry from a tourism focus, and increase capability and infrastructure placing the Gold Coast in a leading position to 
leverage future sporting events and develop a sport industry. He suggested that the GC2018 was an ideal opportunity to showcase the local sporting capacity, which may in turn lead to the movement of National Sport Organisations (NSOs) to the City. The participant also noted that the Gold Coast would be an ideal training ground for athletes leading up to the 2020 Summer Olympics in Tokyo, which shares a similar time zone to Queensland.

"The Commonwealth Games provides a lever for future major events, training camps, and national sporting organisations to be based on the Gold Coast." Participant 2 - Academic expert, sport management

Improved image/employer brand. Three participants were concerned about the highly persuasive nature of social media. They felt that the GC2018 was an excellent opportunity to highlight the Gold Coast for its natural beauty, but also diversify the image by showcasing the health and knowledge precinct and other industries that most people would be unaware of on the Gold Coast. An academic expert participant noted, that given that the Gold Coast is not a capital city and relatively unknown internationally, it has an opportunity to gain substantial advantage in terms of increasing awareness and reputation.

"The Gold Coast is relatively unknown internationally; the Commonwealth Games will help put the city on the map." Participant 24 - Academic expert, economics

An industry group participant raised the point that in February 2017, Gold Coast Tourism launched its 'We are Gold Coast' campaign to shed the city's one-dimensional "Glitter Strip" image. Additionally, a private enterprise participant raised the need to enhance the employer brand of the destination during the GC2018. He said that to grow his business the Gold coast would need to increase skilled migration and diversify to support emerging industry. 
"The Gold Coast's current destination image is a playground for tourist, but this needs to diversify and become a destination for technology and other nontourism companies. This is necessary to stabilise the Gold Coast's economy and to attract and retain the talent necessary for future growth." Participant 12 Private enterprise, telecommunications

Accelerated infrastructure. Three participants from private enterprise and three academic experts discussed the increase in the Gold Coast's public and private funded infrastructure developments. The Gold Coast has benefited from construction jobs and cultural precinct improvements. The participants generally felt that these developments were in the interest of building the City's future and will provide considerable value to the community after the Commonwealth Games has ended. There was some caution about where the construction workers would go post-event, however, others were of the opinion that a number of developments planned occur after the Games should pick-up construction labour slack.

"GC2018 has been instrumental in adrenaline fuelled investment on the Gold

Coast." Participant 16-Academic expert, human resources

In addition, it was not just the acceleration of the infrastructure, but the strategic distribution of event yenues was discussed as a key benefit. The academic expert in urban planning suggested that the distribution supports the natural linear function of the Gold Coast, facilitating the spread across a number of communities. She also outlined from another perspective that the large footprint creates unprecedented challenges in relation to congestion, distribution of benefits and possible disruption to communities. For example, a number of venues are located in suburbs away from the main tourist strip. This will cause congestion on the main highway, but also suburban streets with increased car, bicycle and foot traffic. One private 
enterprise participant suggested that small suburban businesses are not currently anticipating the effect of these changes on their businesses, or in fact, the long-term effect that the changes to public transport, games village will have on the way Gold Coasters' behave and move about the City.

"The distribution of events is good as it supports the spread of assets and links with the existing linear framework of the Gold Coast". Participant 18 - Academic expert, urban planning

Higher real estate prices. The private enterprise real estate participant highlighted that infrastructure and public transport improvements, such as the light rail connecting Broadbeach to Brisbane, is raising property prices. Part of this has been influenced by the light rail corridor having an increased building height limit, in turn making property development more profitable.

"Because of the Games, the Council has relaxed height limits allowing densification in certain areas to make it profitable to redevelop." Participant 13 Private enterprise, real estate

However, from another perspective, an urban planning expert highlighted that while price increases can benefit owners, real estate agents and investors, the demographic likely to be impacted most are low-income families currently living in these areas. As prices increase, these families relocate west and north, away from the CBD.

\section{Potential Challenges}

A number of challenges were also identified, consistent with the perceived benefits, private enterprise stakeholders easily identified broad level challenges, but were less likely to articulate challenges they may face around the Games in their own business settings as illustrated 
in Table 3. Five subthemes were identified, Change in tourist 'type', locals' switching off and temporarily leaving the Gold Coast, unequal distribution of benefits and Commonwealth appeal, and these are presented below.

\section{$<<<$ Insert Table 3 here $>>>$}

Change in tourist 'type'. The tourism private enterprise participant noted that during previous events and shoulder periods, a displacement of the typical leisure and business traveller occurs because of the increasing cost of travel and accommodation. Another participant reflected that the Games visitors do not behave like normal tourists as their stay is motivated by an interest in sport and the Games, rather than sightseeing and leisure activities, thus having implications for tourism enterprises.

"Our business typically doesn't do well when there are large events on the Gold Coast, so we are gearing down and sending our staff on holidays." Participant 8 Private enterprise, tourism

An industry group participant indicated a similar trend might be seen in the restaurant and catering industry with a downturn during the day when spectators are at the events, but a likely increase in evening dining. Another industry group participant also talked about the change in tourist type and the possible downturn of tourism during shoulder periods. To combat this, their precinct has planned for a solid schedule of events after the Games to lure tourist back quickly.

\section{Locals 'switching off' and temporarily departing the Gold Coast. Some participants} highlighted the potential for local residents not to connection with the Games and plan to temporarily leave the city during the event. An academic expert in tourism outlined that this switching off can be problematic as such aversion can have a negative impact on local spending in the Gold Coast region, thereby diminishing the economic gain procured from the event. 
"We are packing up our house, listing it on Airbnb and heading to Cairns."

Participant 8 - Private enterprise, tourism

One industry group participant suggested that in some cases, businesses might consider special promotions or scaling-down operations to offset the switching off local residents. Given the advantage of having local residents be engaged with the event, and supporting local business, it is no surprise that the host city local government has initiated a community outreach program under the Embracing 2018 banner. The local government participant said that the Embracing 2018 legacy program is aimed at engaging locals with the event. One industry group participant identified the alignment between the Games engagement program and the 'We are Gold Coast' campaign by the city's destination marketing organisation as being critical in supporting positive publicity about the games, especially within the local context, and on social media.

Operational Issues. An expert in human resources highlighted a major challenge will be managing staffing and resources to reflect changes in demand. To cope, businesses may expect existing employees to work overtime to satisfy the temporary high demand causing mental and physical exhaustion as indicated by the academic expert in clinical psychology. The short duration of the games may not justify hiring new employees.

"Working long hours during the event can cause mental and physical exhaustion of staff and volunteers." Participant 20-Academic expert, clinical psychology

The temporary increase in demand was also thought to place burden on individual workers, detracting from their experience of the Games. In addition, some employees may consider volunteering, or attending the competition events. This too can apply pressure on employers. 
"A lot of businesses will need their staff to work double shifts, they won't have time to go to any events". Participant 16 - Academic expert, human resources A private enterpriser also highlighted the difficulties of running his business as usual due to staff challenges in getting to work on congested roadways.

"Our business is based in Southport and if the transport infrastructure can't cope our staff will find it difficult to get to work." Participant 12 - Private enterprise, telecommunications

A food supply participant, who had volunteered in the Sydney 2000 Olympic Games, highlighted the potential impact on her business. She argued that the disruption caused by the Games would make it difficult for her business to profit because of increased expenses caused by traffic delays. The participant discussed making deliveries to the Gold Coast from Brisbane at night to minimise trucks on the highway and reduce congestion in the city. Consequently, businesses should investigate the logistics of reeeiving supplies during the night.

"Our business will only be making deliveries to the Gold Coast at night, we can't afford to have our drivers stuck in traffic for hours." Participant 19 - Private enterprise, food supplier

It was anticipated that parking near the competition venues would be restricted, with drop-off zones being utilised and spectators encouraged to use public transport, walk or cycle. An industry group participant noted from his experience from other large-scale sporting events that the uptake of public transport, walking and cycling could cause a 'shadow effect'. The shadow effect has a negative effect on business, as the local streets around venues become busy thoroughfares. 
"In the past, we have found that businesses in the shadow of an event will do poorly." Participant 5 - Industry group, catering

Unequal distribution of benefits. Another challenge of the geographical dispersion of competition events is the uneven distribution of benefits. Some regions or suburbs that are affected by disruption may see reduced visitor numbers and demand. An industry body participant suggested that businesses should assess well in advance if they are affected by road closures, change of routes or increased security.

"Some businesses are better off closing their doors and going on holidays".

Participant 5 - Industry group, catering

The expert in economics discussed the Games Village and the impact that it may have on the city. The village development includes 1,252 residences, a new business hub for health and knowledge, commercial and retail use. The participant said that the major grocery store planned for the village had originally been planned for another suburb and that this demonstrated how the Games could affect the re-distribution of resources.

Commonwealth appeal. The Commonwealth Games participation is limited to 70 competing nations and territories. A problem that faces the Gold Coast is that it is far removed from many Commonwealth countries, and some time zone differences will affect live television coverage and viewing. A participant, not originally from a Commonwealth country discussed a lack of appeal of the Games in non-Commonwealth countries and that they are seen as novice in relation to the Olympic Games.

"The down side of Commonwealth Games is that it is only relevant to Commonwealth countries, and lacks global scale compared to the Olympics." Participant 24-Academic expert, economics 
A key challenge for hosting the Commonwealth Games is that the Gold Coast's primary tourism market is China. As China is not a Commonwealth country, there may be limitations to media penetration.

"Commonwealth countries are not Gold Coast key tourism markets". Participant 1 - Academic expert, event and sport management

\section{Activating Opportunities}

The participants that spoke most frequently about activating opportunities were the academic experts. The industry groups discussed this issue to a lesser extent, and only one of the private enterprise participants articulating possible opportunities. A summary of the discussion is shown in table 4. Private enterprise participants did not fully realise the impact of the Games on their business and therefore could not articulate what they could do to maximise opportunities. Private enterprise that were not part of the tourism/hospitality sector were unable to express any way that they could benefit from the GC2018.

\section{Insert Table 4 here $>>>$}

Firm level. One industry group participant discussed how restaurants could maximise economic impact by fostering yisitor spending. He suggested tactics that encourage patrons to stay longer and spend more, such as targeted promotions that induce impulse purchases, and changes to opening hours to ensure that visitors can patronise businesses before and after the competition events. He commented that Games visitors have different needs to regular tourist and business should plan any changes to normal operating practices and consider the regulatory environment. 


\section{"Businesses should have promotions for guests, and trying to extend their stay. Restaurants and bars should put in lounges with TV footage of events." \\ Participant 5 - Industry group, catering}

One tourism private enterprise participants spoke about promotions targeting event visitors to stimulate spending. She mentioned tools such as event-related promotional packs for official visitors, or the use of a phone app that could assist visitors in finding products and services.

A Local Government participant discussed the procurement packages for goods and services for the GC2018. She had said that while there was good initial interest, the attendance at later sessions dropped off considerable. Obviously disappointed with the outcome, she argued that in general Gold Coast businesses had not engaged in the procurement packages for the Games and therefore should seek opportunities in promoting their business for Games visitors.

"Businesses need to take ownership and get involved. They need to have their brand ready and have an integrated digital presence." Participant 4-Local government

In contrast, a private enterprise participant said that the procurement packages were not suited to local businesses, for example, one business opportunity discussed was the lease and buy back of a large quantity of mattresses. While she wanted to participate in the procurement package, she did not see them as viable.

Coordinated level. One of the private enterprise participants discussed the opportunity for business to develop relationships to pool and share resources. She discussed how a coordinated collaborative approach to share resources such as labour, equipment and vehicles could be advantageous. She felt it could be a win-win. For example, with her business scalingdown over that period, she said it would be a great opportunity for her staff to work in businesses 
with increased demand. While she discussed the benefits of collaborating with other business within the region including competitors to access expertise and assets that would be otherwise be out of reach, she also mentioned that this type of interaction was uncommon.

Three industry group respondents called for collaborative marketing approach to ensure that the tourism destination image portrayed throughout the event was meaningful and positive to minimise any potential negative reports on social media.

"With the increased popularity of social media and review sites, destinations have less control over their brand than ever before. We have effectively outsourced our brand to consumers." Participant 29-Industry group, tourism Two participants, one from private enterprise and an academic expert in tourism discussed the induced visitor as a legacy of the Games. The participants stressed the need for high quality destination marketing that focused on promoting industry, as well as tourism.

"The induced visitor attracted as a legacy of the Commonwealth Games will occur as a result of collaborative marketing by the Game Organisation and DMOs, good service, social media marketing, publicity, and improved destination awareness and image for the Gold Coast." Participant 17 - Academic expert, tourism

One of the industry group participants proposed that a coordinated effort was required to ensure that the host city benefits were long term. He suggested that business should work together and focus on the long-term prosperity that would eventuate with increased tourism numbers.

"The Commonwealth Games is a long term investment, with the heyday to come." Participant 5 - Industry group, catering 


\section{DISCUSSION}

This study responded to a perceived gap in the literature on sport mega-event leveraging and legacy outcomes, focussing on the private enterprise within the host destination. The purpose of the study was to investigate the opportunities and challenges of GC2018 perceived by private enterprise within the host city, and explore the implementation, if any, of strategies to leverage event benefits. Many of the findings from previous studies on this topic were replicated here, suggesting that the academic literature on legacy and leveraging is indeed mirrored in stakeholders' perceptions of the practice of benefit leveraging from large sporting events, with both challenges and opportunities for private enterprise as discussed by all key stakeholder groups. A key finding, however, was that the five stakeholder groups articulated these challenges and opportunities in different ways.

First, it is important to note that the analysis of stakeholder interviews touched on all three key areas, that is i) tourist visitation (e.g. increased tourism demand and supply), ii) urban regeneration (e.g. accelerated infrastructure) and iii) stimulating local business (for example, lever for developing sports industry, higher real estate prices). Tourism impacts were the most obvious and commonly referenced impacts and opportunities, both in terms of visitor numbers (with flow on spending and congestion impacts) as well as destination image impacts, as the Games create opportunities to showcase a regenerated Gold Coast as the main host city. This is reminiscent of findings by Getz (2008), Hede (2007), O’Brien and Chalip (2007), Sun et al. (2013), and Weed (2014). In addition, a number of interviewees noted the upskilling opportunities for local residents, an outcome associated with increased civic pride in the region.

Furthermore, there were some issues raised in our study that do not appear in similar studies of mega-events. For example, the influence of Airbnb on accommodation, dispersal and 
spending patterns of event visitors was a concern for four respondents. The GC2018 represents the first mega-event in a developed country to include Airbnb as a viable (and substantial) accommodation alternative, leading to a certain level of uncertainty around its impact on the Games. In addition, the influence of social media on the destination image was perhaps more prominent in our findings than has been previously reported. Three respondents called for collaborative marketing approaches to ensure that the tourism destination image portrayed through the event is coherent and positive and minimises any potential negative reports on social media.

A key finding from the study, however, was that private enterprise, as reflected by the participants in this study and summarised in Table 2, struggled to articulate benefits specific to them. In most cases, the respondents were more fluent when discussing the challenges presented by hosting the Games (e.g. staffing issues, and traffic disruption to and around the host city), as well generic benefits for the host city, but not specific to business (e.g. more B2B investment opportunities, greater civic pride and improved city infrastructure). Analysis of the interviews experts, local and state government, as well as industry peak bodies, were more likely to lead to discussions of leveraging and legacy. These findings were true not only of the analysis of perceived benefits (Table 2), potential challenges (Table 3), but also of the activating opportunities (Table 4), where both private enterprise and government struggled to articulate activating opportunities to the same extent as industry bodies and academic experts.

These findings highlight that secondary stakeholders of events at this point are struggling to engage with issues of leveraging and legacy, and in particular activating opportunities, but can enter these types of conversations at other levels, for example, challenges and generic benefits of hosting a mega-event. Conversations around managing challenges, and valuing generic benefits 
could perhaps lead secondary stakeholders to engaging with their leveraging opportunities, and how they might contribute to (or benefit from) legacy strategies, and in turn contribute to their leveraging capacities beyond the event (Schulenkorf \& Schlenker, 2017). Furthermore, the different perspectives adopted by private enterprise and government (Table 4) are perhaps best brought together through conversations with third parties, such as academic experts and/or industry bodies. The findings of this study indicate that these groups perhaps have more holistic perceptions of leveraging and its activation and can act as a catalyst for discussions, as advocated by Coghlan et al. (2017).

Furthermore, it not unsurprising that secondary stakeholders such as private enterprise are struggling to engage with issues of leveraging and legacy, as there are many roadblocks to successfully implementing legacy strategies across all levels of stakeholders. For example, the expectation that events should leave a legacy is relatively recent (as described by Chalip in 2006), and highly contextualised to the event's host location, infrastructure, community requirements, etc. (Thomson, Schlenker, \& Schulenkorf, 2013). Furthermore, there is little formal mechanisms for coding and capturing legacy and leveraging knowledge for businesses to share lessons across time and location (Muskat \& Deery, 2017). It currently largely relies on the goodwill of previous event organisers to brief subsequent event managers on successful approaches to legacy and leveraging.

Finally, and possibly in direct relation to the challenges highlighted above, the formal focus has largely been on government department (across state and local government) coordination to ensure that a coherent legacy approach for the host city. Expanding it to secondary stakeholders may yet require some time, engagement and lessons in knowledge transfer. Furthermore, mega-events are sporadic by their very nature, so the temporal lapse 
between events can lead to knowledge and lessons learned being lost across time. Thus, lessons learned in one context, even when successfully captured and passed on, may not be so relevant to the next hosting location.

In terms of recommendations and future research, we propose that the following key points emerge from this study. First, to achieve desirable economic outcomes from large-scale sport events, host governments and business advocates must place greater emphasis on activating event leverage strategies by business. This includes working with the Business schools of host cities' universities to develop industry relevant knowledge and support for business leverage activities. The value of such strategic alignment comes through the existing networks Business Schools harness with local business owners through alumni and consultancy connections built up over many years, and which would continue to provide support long after the temporary event structures of an event have ended. This may also go some way to providing more formal mechanisms for coding and capturing legacy and Yeveraging knowledge, in order to share lessons across time and location.

Policy responses may need to place a greater focus (and resourcing) on working with local business to identify event-related opportunities over the lifespan of the event (that is, preevent, during and post-event) within certain business contexts. Specific actions around this include: the development of case studies from previous events focusing on opportunities (and missed opportunities), successes and pitfalls; facilitated workshopping with like-groups of local business to identify opportunities, develop strategies and map out implementation; and business mentoring programs throughout the event lifespan to provide support for local business to adapt to opportunities in their local environments as they occur. 
To complement a policy focus on business development, there is also a requirement for a coordinated approach to destination marketing, which is relevant to tourism, as well as broader business sectors in the host city (including traditional and social media). These campaigns need to be mapped out to reflect the event lifespan (i.e. pre-event, during and post-event) to capitalise on the unique opportunities presented throughout this time span, as well as ensure that return on investment is maintained into the post-event phase. Part of the business development program should incorporate content and skills for local business in ways to leverage the coordinated campaign, and might include for instance, the shared economy, which has been neglected to date in the event stakeholder literature.

Finally, we provide some suggestions for the future development of this research. Importantly, as noted in our research design, this study has been limited to the host city perspective at a certain point in time in the lead up to an event. Research projects designed as action research which consider the total lifespan of an event would be beneficial in two ways: 1) the action design would help to bridge between policy initiatives and the local business context, assisting with the business derelopment activities, and 2) the total lifespan view would ensure opportunities, challenges, successes and pitfalls could be documented to highlight to future host cities how events can be best leveraged to secure local economic impacts.

\section{CONCLUSION}

In conclusion, this study responded to a gap in the extant research on the role of private enterprise within host communities of sport events, and their ability to leverage benefits from the event. Our study highlighted the significance of local business in contributing to the potential economic outcomes from hosting a large-scale sport event. Yet, our review of literature revealed that this particular topic has not attracted sustained interest or achieved an adequate level of 
development in theory, policy or practice. Our findings suggest a similar disconnect between government policy and initiatives focused on local business and the engagement of business in identifying the event as an opportunity to be leveraged in order to meet strategic objectives, and a lack of activation plans discussed by business representatives. These findings suggest there is a greater need for dedicated initiatives and resources to encourage local businesses to identify and activate event opportunities and harness the significant contribution that local businesses make to local economies.

Looking ahead, the disconnect between top-down intentions for event leveraging and the bottom-up realities for local businesses revealed in our study provides legitimacy for an external agent, such as a host city's university business school, to act as a facilitator of local business networking, knowledge sharing and ideas generating to capitalise on event-related opportunities (Coghlan et al., 2017).

\section{Epilogue}

The authors wish to note developments in this area since completing the data collection for this particular study. Preliminary results from this research were presented back to government and business stakeholders in May 2017 followed by an information and networking opportunity for local businesses. The Queensland State Government also collaborated with local chambers of commerce to provide information workshops for local businesses in October 2017. The City of Gold Coast have also begun their roll out of communique regarding the potential logistical impacts for local businesses. We intend to report on the content and outcomes of these and other initiatives in subsequent phases of this research. 


\section{REFERENCES}

Ahlfeldt, G. M., \& Kavetsos, G. (2012). 17 Outlook, progress and challenges of stadium evaluation. International handbook on the economics of mega sporting events, 279.

Ayyagari, M., Beck, T., \& Demirguc-Kunt, A. (2007). Small and medium enterprises across the globe. Small Business Economics, 29(4), 415-434.

Barreda, A. A., Zubieta, S., Chen, H., Cassilha, M., \& Kageyama, Y. (2017). Evaluating the impact of mega-sporting events on hotel pricing strategies: the case of the 2014 FIFA World Cup. Tourism Review, 72(2), 184-208.

Bernstock, P., \& Poynter, G. (2012). The Housing Crisis. In MacRury (Ed.), London After Recession: A Fictitious Capital? (pp. 116): Ashgate Publishing, Ltd.

Bob, U., \& Swart, K. (2010). Sport events and social legacies. International Journal for the Study of Southern African Literature and Languages, 17(2), 72-95.

Brahham, P., \& Spink, J. (2012). Sport, leisure and culture in the postmodern city. In B. Graham (Ed.), (pp. 9-32): Ashgate Publishing, Ltd.

Cashman, R. (2006). The bitter-sweet awakening: The legacy of the Sydney 2000 Olympic Games: Pan Macmillan.

Cashman, R., \& Horne, J. (2013). Managing legacy. Managing the Olympics (pp. 50-65). Springer.

Chalip, L. (2001). Sport and tourism: Capitalising on the linkage. In K. A. Schilling (Ed.), The Business of Sport (Vol. 3, pp. 77-90). Oxford: Meyer \& Meyer Oxford.

Chalip, L. (2006). Towards social leverage of sport events. Journal of Sport \& Tourism, 11(2), $109-127$. 
Chalip, L. (2017). Trading legacy for leverage. In I. Brittain, J. Bocarro, T. Byers, \& K. Swart (Eds.), Legacies and mega events: Fact or fairy tales? (pp. 25-41). Routledge.

Chalip, L., Green, B. C., \& Hill, B. (2003). Effects of sport event media on destination image and intention to visit. Journal of sport management, 17(3), 214-234.

Chalip, L., \& Leyns, A. (2002). Local business leveraging of a sport event: Managing an event for economic benefit. Journal of sport management, 16(2), 132-158.

Chalip, L., Ritchie, B. W., \& Adair, D. (2004). Beyond impact: A general model for sport event leverage. Sport Tourism: Interrelationships, Impacts and Issues, 226-252.

Christie, L., \& Gibb, K. (2015). A collaborative approach to event-led regeneration: The governance of legacy from the 2014 Commonwealth Games. Local Economy, 30(8), $871-887$.

City of Gold Coast. (2011). Gold Coast City Candidate City File. Retrieved from https://thecgf.com/sites/default/files/2018-03/Gold_Coast_VOL_1.pdf

Coghlan, A., Sparks, B., Liu, W., \&Winlaw, M. (2017). Reconnecting with place through events: Collaborating with precinct managers in the placemaking agenda. International Journal of Event and Festival Management, 8(1), 66-83.

Crompton, J. (2014). Proximate development: an alternate justification for public investment in major sport facilities?. Managing Leisure, 19(4), 263-282.

Demir, A., Eliöz, M., Çebi, M., \& Yamak, B. (2015). The economic development and tourism effects of the Olympics. Anthropologist, 19(3), 811-817.

Dolles, H., \& Söderman, S. (2008). Mega-sporting events in Asia-Impacts on society, business and management: An introduction. Asian Business \& Management, 7(2), 147-162. 
Emery, P. (2010). Past, present, future major sport event management practice: The practitioner perspective. Sport Management Review, 13(2), 158-170.

Essex, S., \& Chalkley, B. (2004). Mega-sporting events in urban and regional policy: a history of the Winter Olympics. Planning Perspectives, 19(2), 201-204.

Etikan, I., Musa, S. A., \& Alkassim, R. S. (2016). Comparison of convenience sampling and purposive sampling. American Journal of Theoretical and Applied Statistics, 5(1), 1-4.

Fairley, S., Lovegrove, H., Newland, B., \& Green, B. C. (2016). Image recovery from negative media coverage of a sport event: Destination, venue, and event considerations. Sport Management Review, 19(3), 352-360.

Ferson, M. J., \& Ressler, K. (2005). Bound for Sydney town: health surveillance on international cruise vessels visiting the Port of Sydney. Medical Journal of Australia, 182(8), 391-394.

Gardiner, S., \& Chalip, L. (2006). Leveraging a mega-event when not the host city: Lessons from pre-Olympic training: Sustainable Tourism CRC.

Getz, D. (2008). Event tourism: Definition, evolution, and research. Tourism Management, $29(3), 403-428$.

Getz, D., \& Fairley, S. (2004).Media management at sport events for destination promotion: Case studies and concepts. Event Management, 8(3), 127-139.

Gold Coast 2018. (2017). Gold Coast 2018 XXI Commonwealth Games. Retrieved from https://www.gc2018.com/games

GOLDOC. (2014). Sustainability Report 2014-2015. Retrieved from https://www.gc2018.com/about/sustainability

Gratton, C., \& Preuss, H. (2008). Maximizing Olympic impacts by building up legacies. The International Journal of the History of Sport, 25(14), 1922-1938. 
Hall, C. M. (2006). Urban entrepreneurship, corporate interests and sports mega-events: the thin policies of competitiveness within the hard outcomes of neoliberalism. The Sociological Review, 54(s2), 59-70.

Hanstad, D. V., Parent, M. M., \& Kristiansen, E. (2013). The Youth Olympic Games: the best of the Olympics or a poor copy?. European Sport Management Quarterly, 13(3), 315-338.

Hede, A. (2007). Managing special events in the new era of the triple bottom line. Event Management, 11(1-2), 13-22.

Jago, L., Dwyer, L., Lipman, G., van Lill, D., \& Vorster, S. (2010). Optimising the potential of mega-events: an overview. International Journal of Event and Festival Management, $1(3), 220-237$.

Johnson, M. P. (2016). Two Decades of Sustainability Management Tools for SMEs: How Far Have We Come?. Journal of Small Business Management, 54(2), 481-505.

Jones, K. (2017). Boost to business, trade and inyesstment in Queensland with Trade 2018. Retrieved from http://statements.qld.gov.au/Statement/2017/6/8/boost-to-business-tradeand-investment-in-queensland-with-trade-2018

Kasimati, E. (2003). Economic aspects and the Summer Olympics: a review of related research. International Journal of Tourism Research, 5(6), 433-444.

Kassens-Noor, E., Wilson, M., Müller, S., Maharaj, B., \& Huntoon, L. (2015). Towards a megaevent legacy framework. Leisure Studies, 34(6), 665-671.

Kellett, P., Hede, A., \& Chalip, L. (2008). Social policy for sport events: Leveraging (relationships with) teams from other nations for community benefit. European Sport Management Quarterly, 8(2), 101-121. 
Kwiatkowski, G. (2016). Economic Impact of Event Attendees' Spending On a Host Region: A Review of the Research. Event Management, 20(4), 501-515.

Leopkey, B., \& Parent, M. (2012). Olympic Games legacy: From general benefits to sustainable long-term legacy. The International Journal of the History of Sport, 29(6), 924-943.

Leopkey, B., \& Parent, M. (2013). The Governance of Olympic Legacy: A Theoretical Model. Paper presented at the European Association of Sport Management, Istanbul, Turkey.

Mackellar, J., \& Nisbet, S. (2017). Sport events and integrated destination development. Current Issues in Tourism, 20(13), 1320-1335.

Malecki, E. J. (2018). Entrepreneurs, networks, and economic development: A review of recent research. J. Katz \& A. Corbett (Ed.) Reflections and extensions on key papers of the first twenty-five years of advances (Advances in Entrepreneurship, Firm Emergence and Growth, Vol. 20) (pp. 71-116). Emerald Publishing Limited.

Merrilees, B., Getz, D., \& O'Brien, D. (2005), Marketing stakeholder analysis: branding the brisbane goodwill games. European Journal of Marketing, 39(9-10), 1060-1077.

Müller, M. (2012). Popular perception of urban transformation through megaevents: understanding support for the 2014 Winter Olympics in Sochi. Environment and Planning C: Government and Policy, 30(4), 693-711.

Muskat, B., \& Deery, M. (2017). Knowledge transfer and organizational memory: an events perspective. Event Management, 21(4), 431-447.

Neuman, L. (2006). Social research methods: Qualitative and quantitative approaches $\left(6^{\text {th }}\right.$ Ed.). Boston: Pearson. 
O'Brien, D. (2005). Strategic business leveraging of a mega sport event: The Sydney 2000 Olympic Games experience. Gold Coast: Sustainable Tourism Cooperative Research Centre.

O’Brien, D. (2006). Event business leveraging the Sydney 2000 Olympic games. Annals of tourism research, 33(1), 240-261.

O'Brien, D. (2007). Points of leverage: Maximizing host community benefit from a regional surfing festival. European Sport Management Quarterly, 7(2), 141-165.

O’Brien, D., \& Chalip, L. (2007). 19 Sport events and strategic leveraging: Pushing towards the triple bottom line. Tourism Management: Analysis, Behaviour, and Strategy, 318.

O’Brien, D., \& Gardiner, S. (2006). Creating sustainable mega event impacts: Networking and relationship development through pre-event training. Sport Management Review, 9(1), $25-47$.

Pentifallo, C., \& VanWynsberghe, R. (2015). Mega-event impact assessment and policy attribution: embedded case study, social housing, and the 2010 Winter Olympic Games. Journal of Policy Reséarch in Tourism, Leisure and Events, 7(3), 266-281.

Preuss, H. (2011). A method for calculating the crowding-out effect in sport mega-event impact studies: The 2010 FIFA World Cup. Development Southern Africa, 28(3), 367-385. doi:10.1080/0376835X.2011.595995

Preuss, H., \& Alfs, C. (2011). Signaling through the 2008 Beijing Olympics-Using mega sport events to change the perception and image of the host. European Sport Management Quarterly, 11(1), 55-71.

PricewaterhouseCoopers (PwC). (2017). Sports: The most disrupted of all industries? 
Retrieved from, https://www.thinksport.org/en/latest-news-and-views/new-pwc-surveyidentifies-sports-as-the-most-disrupted-of-all-industries-6463

Queensland Government. (2017). Ahead of the Games. Retrieved from

https://www.publications.qld.gov.au/dataset/ahead-of-the-games/resource/f55836aa$\underline{3666-4 e a 2-b 69 a-3 f c 5742 c 3028}$

Ritchie, J. R. B., \& Smith, B. H. (1991). The impact of a mega-event on host region awareness: A longitudinal study. Journal of Travel Research, 30(1), 3-10.

Samatas, M. (2014). Surveilling the 2004 Athens Olympics in the afermat of 9/11. In C. J. Bennett \& K. Haggerty (Eds.), Security games: surveillance and control at mega-events. New York: Routledge.

Sbaraini, A., Carter, S. M., Evans, R. W., \& Blinkhorn, A. (2011). How to do a grounded theory study: A worked example of a study of dental practices. BMC Medical Research Methodology, 11(1), 128.

Schulenkorf, N. (2010). Bridging the divide: The role of sport events in contributing to social development between-disparate communities. European Journal of Tourism Research, 3(2), 127.

Schulenkorf, N., \& Schlenker, K. (2017). Leveraging Sport Events to Maximize Community Benefits in Low-and Middle-Income Countries. Event Management, 21(2), 217-231.

Smith, A. (2014). Leveraging sport mega-events: New model or convenient justification? Journal of Policy Research in Tourism, Leisure and Events, 6(1), 15-30.

Smith, A., \& Fox, T. (2007). From'event-led'to'event-themed'regeneration: the 2002 Commonwealth Games Legacy Programme. Urban Studies, 44(5-6), 1125-1143. 
Sun, Y., Rodriguez, A., Wu, J., \& Chuang, S. (2013). Why hotel rooms were not full during a hallmark sporting event: The 2009 World Games experience. Tourism Management, 36, 469-479. doi:doi.org/10.1016/j.tourman.2012.09.011

Teigland, J. (1999). Mega-events and impacts on tourism; the predictions and realities of the Lillehammer Olympics. Impact Assessment and Project Appraisal, 17(4), 305-317.

Thompson, J. (2015). Sydney Games: a lasting legacy? Retrieved from http://www.abc.net.au/news/2010-09-15/sydney-games-a-lasting-legacy/2260648

Thomson, A., Schlenker, K., \& Schulenkorf, N. (2013). Conceptualizing sport event legacy. Event Management, 17(2), 111-122.

Thomson, A., Schlenker, K., Schulenkorf, N., \& Brooking, E.(Eds.). (2017). The Social and Environmental Consequences of Hosting Mega-Sport Events: Routledge.

Tien, C., Lo, H., \& Lin, H. (2011). The economic benefits of mega events: A myth or a reality? A longitudinal study on the Olympic Gamés. Journal of Sport Management, 25(1), 1123.

Tiew, F., Holmes, K., \& De Bussy, N. (2015). Tourism events and the nature of stakeholder power. Event Management, 19(4), 525-541.

Todd, L., Leask, A., \& Ensor, J. (2017). Understanding primary stakeholders' multiple roles in hallmark event tourism management. Tourism Management, 59, 494-509.

Tracy, S. J. (2010). Qualitative quality: Eight "big-tent" criteria for excellent qualitative research. Qualitative Inquiry, 16(10), 837-851.

Veal, A., Toohey, K., \& Frawley, S. (2012). The sport participation legacy of the Sydney 2000 Olympic Games and other international sporting events hosted in Australia. Journal of Policy Research in Tourism, Leisure and Events, 4(2), 155-184. 
Waitt, G. (2008). Urban festivals: geographies of hype, helplessness and hope. Geography Compass, 2(2), 513-537.

Weed, M. (2014). Is tourism a legitimate legacy from the Olympic and Paralympic Games? An analysis of London 2012 legacy strategy using programme theory. Journal of Sport \& Tourism, 19(2), 101-126.

Xing, X., \& Chalip, L. (2006). Effects of Hosting a Sport Event on Destination Brand: A Test of Co-branding and Match-up Models. Sport Management Review, 9(1), 49-78. doi:https://doi.org/10.1016/S1441-3523(06)70019-5

Yin, R. (2011). Applications of case study research ( $3^{\text {rd }}$ Ed.). London: Sage Publications. 
Table 1: Participant profiles

\begin{tabular}{|c|c|c|}
\hline Participant & Stakeholder Group & Industry/expertise \\
\hline 1 & Academic expert & Event \\
\hline 2 & Academic expert & Sport \\
\hline 3 & Academic expert & Higher education \\
\hline 4 & Local Government & Government \\
\hline 5 & Industry Group & Catering \\
\hline 6 & Private enterprise & Legal \\
\hline 7 & Private enterprise & Finance \\
\hline 8 & Private enterprise & Tourism \\
\hline 9 & Private enterprise & Retail \\
\hline 10 & Academic expert & Tourism \\
\hline 11 & Private enterprise & IT \\
\hline 12 & Private enterprise & Telecommunications \\
\hline 13 & Private enterprise & Real Estate \\
\hline 14 & Industry Group & Accommodation \\
\hline 15 & Academic expert & Event \\
\hline 16 & Academic expert & Human resources \\
\hline 17 & Academic expert & Tourism \\
\hline 18 & Expert & Urban planning \\
\hline 19 & Private enterprise & Food Supplier \\
\hline 20 & Academic expert & Clinical psychology \\
\hline 21 & Academic expert & Urban planning \\
\hline 22 & Academic expert & Tourism \\
\hline 23 & Private enterprise & Tourism \\
\hline 24 & Academic expert & Economics \\
\hline 25 & Academic expert & Event \\
\hline 26 & Industry Group & Business development \\
\hline 27 & State Government & Government \\
\hline 28 & State Government & Government \\
\hline 29 & Industry Group & Tourism \\
\hline 30 & Event Management & GC2018 \\
\hline 31 & Private enterprise & Accommodation \\
\hline 32 & Industry Group & Tourism \\
\hline 33 & Academic expert & Tourism \\
\hline 34 & Local Government & Government \\
\hline
\end{tabular}


Table 2: Perceived benefits - summary by stakeholder

\begin{tabular}{|c|c|c|c|c|}
\hline Theme & $\begin{array}{l}\text { Academic } \\
\text { expert }\end{array}$ & $\begin{array}{l}\text { Private } \\
\text { enterprise }\end{array}$ & Industry group & Government \\
\hline $\begin{array}{l}\text { Increased } \\
\text { tourism demand } \\
\text { and supply }\end{array}$ & $\checkmark$ & $\checkmark$ & & $x$ \\
\hline $\begin{array}{l}\text { Upskilling and } \\
\text { civic pride }\end{array}$ & $\checkmark$ & $x$ & $\checkmark$ & $\checkmark$ \\
\hline $\begin{array}{l}\text { Lever for future } \\
\text { events and } \\
\text { developing sports } \\
\text { industry }\end{array}$ & $\checkmark$ & $x$ & $x$ & $x$ \\
\hline $\begin{array}{l}\text { Improved } \\
\text { image/employer } \\
\text { brand }\end{array}$ & $\checkmark$ & & & $x$ \\
\hline $\begin{array}{l}\text { Accelerated } \\
\text { infrastructure }\end{array}$ & $\checkmark$ & & 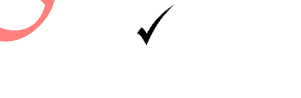 & $x$ \\
\hline $\begin{array}{l}\text { Higher real- } \\
\text { estate prices }\end{array}$ & $\checkmark$ & & $x$ & $\boldsymbol{x}$ \\
\hline Summary & $\begin{array}{l}\text { This group } \\
\text { identified many } \\
\text { benefits for } \\
\text { business and the } \\
\text { Gold Coast } \\
\text { from the } \\
\text { Gd2018. Many } \\
\text { notions were } \\
\text { linked to } \\
\text { experience from } \\
\text { previous events } \\
\text {. }\end{array}$ & $\begin{array}{l}\text { Most } \\
\text { participants } \\
\text { could not } \\
\text { articulate } \\
\text { benefits for their } \\
\text { business. Howe } \\
\text { ver, the } \\
\text { improvement in } \\
\text { infrastructure } \\
\text { and transport } \\
\text { was identified. }\end{array}$ & $\begin{array}{l}\text { Few industry } \\
\text { participants } \\
\text { (mainly linked } \\
\text { to the tourism } \\
\text { industry) were } \\
\text { able to identify } \\
\text { benefits to } \\
\text { business. }\end{array}$ & $\begin{array}{l}\text { Local } \\
\text { government } \\
\text { focus was on } \\
\text { the lack of } \\
\text { involvement of } \\
\text { local business in } \\
\text { the procurement } \\
\text { packages. State } \\
\text { government was } \\
\text { focused on } \\
\text { producing } \\
\text { resources assist } \\
\text { businesses. }\end{array}$ \\
\hline
\end{tabular}


Table 3: Potential challenges - summary by stakeholder

\begin{tabular}{|c|c|c|c|c|}
\hline Theme & $\begin{array}{l}\text { Academic } \\
\text { expert }\end{array}$ & $\begin{array}{l}\text { private } \\
\text { enterprise }\end{array}$ & Industry group & Government \\
\hline $\begin{array}{l}\text { Change in tourist } \\
\text { type }\end{array}$ & $\checkmark$ & $\checkmark$ & & $x$ \\
\hline $\begin{array}{l}\text { Locals 'switching } \\
\text { off' }\end{array}$ & $\checkmark$ & $x$ & $\checkmark$ & $x$ \\
\hline $\begin{array}{l}\text { Operational } \\
\text { issues }\end{array}$ & & $\checkmark$ & & $\checkmark$ \\
\hline $\begin{array}{l}\text { Unequal } \\
\text { distribution of } \\
\text { benefits }\end{array}$ & $\checkmark$ & $\boldsymbol{x}$ & & $\mathbf{x}$ \\
\hline $\begin{array}{l}\text { Commonwealth } \\
\text { appeal }\end{array}$ & & $x$ & $x$ & $x$ \\
\hline Summary & $\begin{array}{l}\text { This group } \\
\text { easily identified } \\
\text { potential } \\
\text { disruptors both } \\
\text { digital and } \\
\text { logistical. }\end{array}$ & $\begin{array}{l}\text { Some } \\
\text { participants in } \\
\text { the tourism } \\
\text { industry were } \\
\text { able to identify } \\
\text { challenges } \\
\text { based on their } \\
\text { experience from } \\
\text { previous events } \\
\text { on the Gold } \\
\text { Coast }\end{array}$ & $\begin{array}{l}\text { This group } \\
\text { easily identified } \\
\text { a number of } \\
\text { challenges for } \\
\text { both their } \\
\text { members and } \\
\text { the Gold Coast. }\end{array}$ & $\begin{array}{l}\text { Local } \\
\text { government } \\
\text { noted that most } \\
\text { business would } \\
\text { find their lack } \\
\text { of professional } \\
\text { branding a } \\
\text { hindrance } \\
\text { during the } \\
\text { games. }\end{array}$ \\
\hline
\end{tabular}


Table 4: Activating opportunities - summary by stakeholder

\begin{tabular}{|c|c|c|c|c|}
\hline Theme & $\begin{array}{l}\text { Academic } \\
\text { expert }\end{array}$ & $\begin{array}{l}\text { Private } \\
\text { enterprise }\end{array}$ & Industry group & Government \\
\hline Firm level & $\checkmark$ & $x$ & $\checkmark$ & $\checkmark$ \\
\hline $\begin{array}{l}\text { Coordinated } \\
\text { level }\end{array}$ & $\checkmark$ & $\checkmark$ & $\checkmark$ & $x$ \\
\hline Summary & $\begin{array}{l}\text { This group } \\
\text { easily identified } \\
\text { ways that } \\
\text { businesses and } \\
\text { the Gold Coast } \\
\text { could benefit } \\
\text { from } \\
\text { opportunities. }\end{array}$ & $\begin{array}{l}\text { Most participant } \\
\text { could not } \\
\text { articulate } \\
\text { potential ways } \\
\text { to create } \\
\text { opportunities. } \\
\text { One participant, } \\
\text { who has worked } \\
\text { with the } \\
\text { university on } \\
\text { another research } \\
\text { project was able } \\
\text { to articulate a } \\
\text { coordinated } \\
\text { approach. }\end{array}$ & $\begin{array}{l}\text { One participant } \\
\text { in particular } \\
\text { easily } \\
\text { articulated ways } \\
\text { in which } \\
\text { businesses } \\
\text { could profit } \\
\text { based on his } \\
\text { experience from } \\
\text { previous mega } \\
\text { eyents. }\end{array}$ & $\begin{array}{l}\text { Local } \\
\text { government put } \\
\text { the control of } \\
\text { benefitting in } \\
\text { the hands of } \\
\text { business. } \\
\text { State } \\
\text { government } \\
\text { were using } \\
\text { collateral from } \\
\text { previous } \\
\text { Commonwealth } \\
\text { Games to assist } \\
\text { local business. }\end{array}$ \\
\hline
\end{tabular}




Perceived Benefits
- Increased tourism demand and supply
- Upskilling and Civic pride
- Lever for future events and developing sports industry
- Improved destination image and employer brand
- Accelerated infrastructure
- Higher real-estate prices
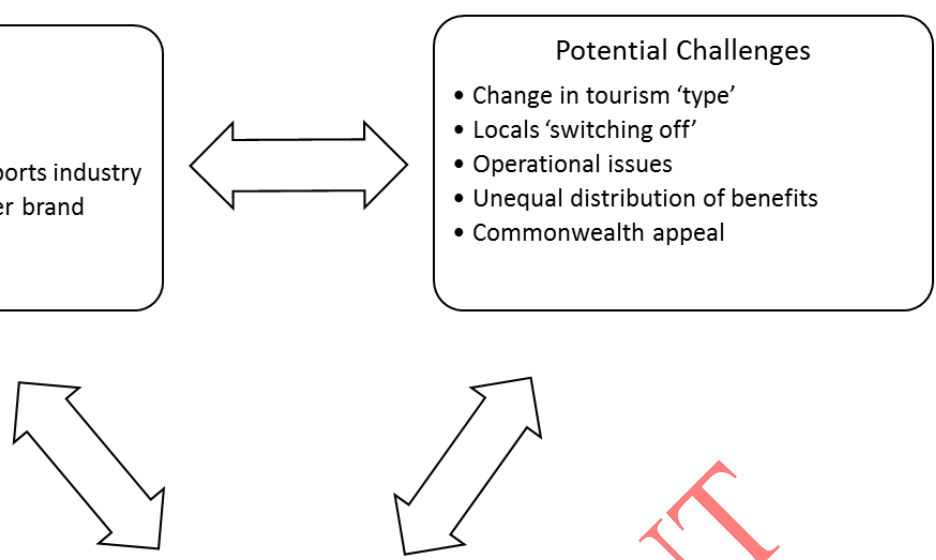

Activating Benefits

- Firm level

- Coordinated level

Figure 1: Visual summary of main and sub-themes

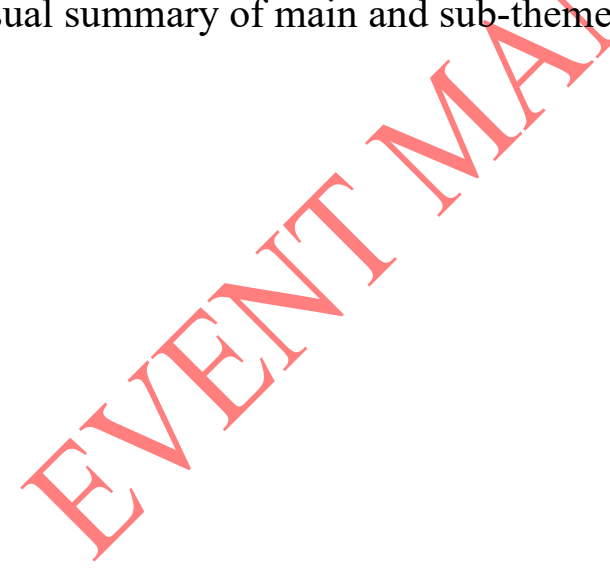

